\title{
Prognostic significance of miR-23b in combination with P-gp, MRP and LRP/MVP expression in non-small cell lung cancer
}

\author{
M. JANIKOVA ${ }^{1,2, \neq}$, V. ZIZKOVA ${ }^{1, *}$, J. SKARDA ${ }^{1,2, *}$, G. KHARAISHVILI ${ }^{1,2}$, L. RADOVA $^{3}$, Z. KOLAR ${ }^{1,2}$ \\ ${ }^{1}$ Department of Clinical and Molecular Pathology and Laboratory of Molecular Pathology; ${ }^{2}$ Institute of Molecular and Translational Medicine, \\ Faculty of Medicine and Dentistry, Palacky University Olomouc and University Hospital Olomouc; ${ }^{3}$ CEITEC MU, Brno, Czech Republic
}

"Correspondence: jojos@email.cz

${ }^{*}$ Contributed equally to this work.

Received May 14, 2015 / Accepted November 13, 2015

\begin{abstract}
Recently, miR-23b has emerged as a promising new cancer biomarker but its role in lung cancer has not been established yet. Patients still do not respond well to available treatments, probably due to expression of multidrug resistance (MDR) proteins, such as P-gp, MRP and LRP/MVP. The aim of this study was to determine the role of miR-23b in non-small cell lung cancer (NSCLC) and its relationship to the patient outcome together with MDR transporter proteins. We immunohistochemically evaluated expression of P-gp, MRP and LRP/MVP and quantified the relative levels of miR-23b in 62 NSCLC patients' samples. The prognostic significance of miR-23b and MDR proteins was tested by Kaplan-Meier and Cox-regression analysis. Our results showed that miR-23b is mostly downregulated in NSCLC samples (57/62) and that its upregulation in tumors is connected with longer progression-free survival (PFS; $\mathrm{P}=0.065$ ) and overall survival (OS; $\mathrm{P}=0.048$ ). The Cox proportional hazard model revealed that the risk of death or relapse in NSCLC patients with miR-23b downregulation increases together with LRP/MVP expression and both risks decrease with miR-23b upregulation $\left(\mathrm{HR}_{\mathrm{PFS}}=4.342, \mathrm{P}_{\mathrm{PFS}}=0.022 ; \mathrm{HR}_{\mathrm{OS}}=4.408, \mathrm{P}_{\mathrm{OS}}\right.$ $=0.015$ ). Our findings indicate that miR-23b, especially in combination with LRP/MVP expression, might serve as a suitable prognostic biomarker for NSCLC patients.
\end{abstract}

Key words: non-small cell lung cancer (NSCLC), MiR-23b, P-gp, MRP, LRP/MVP, prognosis

Lung cancer is a major cause of cancer mortality worldwide and non-small cell lung cancer (NSCLC) represents approximately $80-85 \%$ of all cases [1]. The problem is that many NSCLC patients do not respond to the therapy due to the emergence of multidrug resistance (MDR). The most studied proteins underlying this phenomenon are $\mathrm{P}$-glycoprotein $(\mathrm{P}$ gp/ABCB1/MDR1), Multidrug resistance-related protein 1 (MRP/ABCC1/MRP1) and Lung-resistance related protein/ Major vault protein (LRP/MVP).

P-gp and MRP belong to the family of ATP binding casette (ABC) transporters. P-gp actively transports hydrophobic, positively charged and neutral molecules, while MRP pumps negatively charged molecules (mainly glutathione conjugates) from the cell to the extracellular space [2-5]. They are localized in the cytoplasmic membrane and they are normally expressed in organs, such as lung, intestine or the hemato-encephalic barrier which are in contact with environment and xenobiotics (toxins and drugs). The physiological function of P-gp and
MRP is to export toxic metabolites and xenobiotics entering the cells from the environment and to protect the cells from damage [6-10]. These ABC-transporters are aberrantly expressed in tumor cells. Activation of their expression in cancer cells is responsible for the export of diverse chemotherapeutics from the cells $[5,7,8,11,12]$.

LRP/MVP is a ribonucleoprotein particle able to transport drugs such as platinum derivatives from the nucleus to the cytoplasm. After that, these compounds can be transported outside from the cells by ABC-transporters [13-15].

Expression of P-gp, MRP and LRP/MVP is often observed in NSCLC samples and it is believed that these molecules play a major role in the emergence of multidrug resistance $[5,7,8,16]$.

Recent studies have shown that miRNAs play an important role in development, differentiation, DNA damage response, proliferation, apoptosis and other processes. They are also involved in diverse regulatory pathways and they can affect 
carcinogenesis, chemoresistance and radioresistance [17-21]. For these reasons, miRNAs whose expression may be increased or decreased in tumors could be called a class of oncogenes or tumor suppressors and they might be used as biomarkers for monitoring carcinogenesis [17, 22]. Radiotherapy, chemotherapy and biological therapy are frequently used for treating advanced forms of NSCLC but in recent years, RNA interference (RNAi) has also been introduced $[1,23]$. RNAi is a highly conserved molecular mechanism of post-transcriptional gene silencing. Functional units of RNAi in humans are mainly small ( 22 nucleotides) non-coding, endogenous, single-stranded RNAs, called microRNAs (miRNAs). Based on complementarity, miRNAs bind to the target mRNA which is either completely degraded or prevented from translation [23]. Currently, according to miRBase 21, 2588 mature human miRNAs are known to regulate many protein-coding genes [24].

Recently, miR-23b has emerged as a promising molecule that may be involved in tumor development and metastasis. It behaves as a tumor-suppressor or as an oncogenic miRNA in time- and tissue-dependent manner [25]. Owing to its dual role, miR-23b in tumors targets different molecules and regulates oncogenes supporting proliferation and metastasis formation, such as Src kinase, AKT, SNAIL and ZEB1, or tumor-suppressors having an apoptotic and anti-metastatic effect (for example Nischarin, VHL and PTEN) [26-31]. Downregulation of miR-23b was observed in prostate, bladder and thyroid cancer. Patients with higher levels of miR-23b had better prognosis than those with lower levels [26, 28, 32]. Upregulation of miR-23b was detected in renal, breast cancer and gliomas [29-31] and its upregulation was connected with poor patient's outcome.

Prognostic significance of miR-23b has not been studied in NSCLC yet. For this reason, we quantified level of miR-23b in NSCLC patient samples. Identification of its significance could be crucial for its usage as a biomarker. We compared its expression with the expression of known transporter proteins P-gp, MRP and LRP/MVP involved in the emergence of MDR. Finally, we created a regression model for assessing patient risk of death or relapse.

\section{Patients and methods}

Patients and their clinical data. Formalin-fixed and paraffin-embedded (FFPE) tissue samples of lung cancer from 1996-2000 were obtained from the archives of the Department of Clinical and Molecular Pathology, Faculty of Medicine and Dentistry, Palacky University Olomouc and University Hospital Olomouc. The sample comprised 62 patients with lung cancer, 55 males and 7 females (age range 33 to 78 years), after approval by the ethics committee of University Hospital and Faculty of Medicine and Dentistry, Palacky University Olomouc. In this cohort, 30 tumors were classified as adenocarcinomas (ADCs), 26 as squamous cell carcinomas (SCCs) and 6 as large cell carcinomas (LCCs). 18 patients were in stage
I/II and 33 patients in stage III/IV. For the rest of the patients, the stage was unknown. 22 patients received chemotherapy. 17 of them underwent platinum based chemotherapy regime and the rest were treated with different chemotherapeutics, such as fluorouracil, doxorubicin or taxanes. The characteristics of patients are summarised in Table 1. The clinicopathological parameters, progression free survival (PFS) and overall survival (OS), were monitored over 175 months.

Tissue microarray construction. Tumor tissue microarrays (TMAs) were constructed using 62 formalin-fixed and paraffin-embedded primary lung cancer specimens. The tissue areas for sampling were selected by pathologists on the basis of visual alignment with corresponding $\mathrm{H} \& \mathrm{E}$ stained section and were taken from two to four tissue cores from a tumor block and were replaced into recipient paraffin block using a tissue microarrayer Galileo TMA CK3500 (BioRep, Milan, Italy).

Immunohistochemical staining of P-gp, MRP and LRP/ MVP. The TMA sections were deparaffinized and an indirect immunohistochemistry technique was used. Then LRP/ MVP antigen was unmasked in citrate buffer $(\mathrm{pH} 6)$ and MRP in Target Retrieval Solution, High pH (10x) (Dako, Glostrup, Denmark). The sections for detection of P-gp were not pre-treated because the ABCB1 / P Glycoprotein Mouse anti-Human Monoclonal (UIC2) Antibody (LS-C58240-100, LifeSpan Biosciences, Inc., Seattle, WA, USA) targets the extracellular epitope of P-gp protein [33]. This antibody was diluted in a ratio 1:200. Both Monoclonal Antibody to MRP1 (human) (MRPm5) (ALX-801-012-C125, Enzo Life Sciences. Inc., Farmingdale, NY, USA) and Monoclonal Antibody to MVP/LRP (human), mAb (MVP-37) (LMR5) (ALX-801026-C125, Enzo Life Sciences. Inc., Farmingdale, NY, USA)

Table 1. Characteristics of patients.

\begin{tabular}{lccc}
\hline Characteristics & Subgroups & Number & $\%$ \\
\hline \multirow{2}{*}{ Gender } & Male & 55 & 88.7 \\
& Female & 7 & 11.3 \\
\hline \multirow{2}{*}{ Age in years } & $<60$ & 31 & 50.0 \\
& $\geq 60$ & 31 & 50.0 \\
\hline \multirow{4}{*}{ Histological subtype } & ADC & 30 & 48.4 \\
& SCC & 26 & 41.9 \\
& LCC & 6 & 9.7 \\
\hline \multirow{4}{*}{ Stage at diagnosis } & I & 13 & 21.0 \\
& II & 5 & 8.1 \\
& IIIA & 20 & 32.3 \\
& IIIB & 5 & 8.1 \\
& IV & 8 & 12.9 \\
Chemotherapy & Not specified & 11 & 17.7 \\
\hline Total & Yes & 22 & 35.5 \\
\hline ADC - adenocarcinoma, SCC - squamous cell carcinoma, LCC - large cell \\
carcinoma. & No & 31 & 50.0 \\
& Not specified & 9 & 14.5 \\
\hline
\end{tabular}



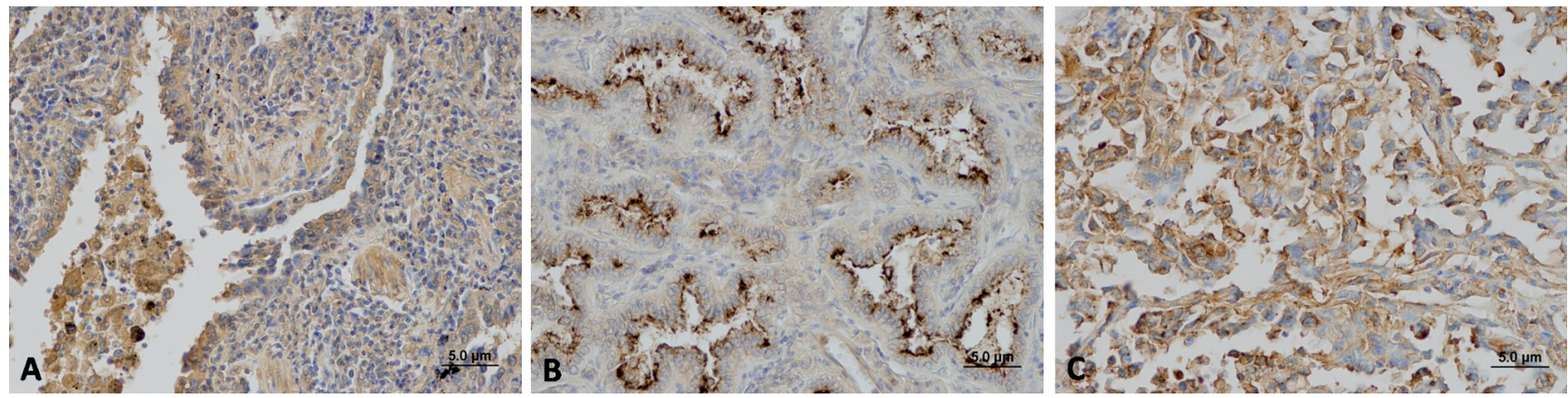

Figure 1. Immunohistochemical expression of P-gp, MRP and LRP/MVP. Representative images of immunohistochemical staining of P-gp (A), MRP (B) and LRP/MVP (C) in NSCLC samples. Magnification 200x.

were used at a dilution 1:200. Visualisation was made by EnVisionTM+ Dual Link (Dako, Glostrup, Denmark) and nuclei were counterstained with haematoxylin. Stained sections were observed under an optical microscope and images were captured with a DP71 camera (Olympus, Tokyo, Japan). The expression of P-gp, MRP and LRP/MVP were semi quantitatively assessed by two pathologists by estimation of the percentage of positive cells as very low $(\leq 0.1)$, low $(\leq 0.3)$, moderate $(\leq 0.6)$ or high $(>0.6)$.

Isolation of total RNA. Total RNA isolation from corresponding tissue cores obtained by tissue microarrayer Galileo TMA CK3500 [34] was performed using the RecoverAll ${ }^{\mathrm{Tm}}$ Total Nucleic Acid Isolation Kit for FFPE (Applied Biosystems, Foster City, CA, USA) according to the manufacturer's instructions. The concentration of total RNA was measured using NanoDrop ND-1000 spectrophotometer (NanoDrop Technologies, Wilmington, Delaware, USA) and then RNA was stored at $-80^{\circ} \mathrm{C}$ until use.

Reverse transcription. TaqMan ${ }^{\circledR}$ MicroRNA Reverse Transcription Kit (Applied Biosystems, Foster City, CA, USA) was used according to manufacturer's protocol. For reverse transcription, $10 \mathrm{ng}$ of total RNA was used and total volume of reaction was $15 \mu$ l. Pooled gene-specific primers for miR-23b and RNA, U6 small nuclear 2 (RNU6B) (Applied Biosystems, Foster City, CA, USA) were added to the reverse transcription polymerase chain reaction (RT-PCR). RT-PCR product was then pre-amplified according to protocol using TaqMan $^{\circledR}$ PreAmp Master Mix (2x) (Applied Biosystems, Foster City, CA, USA) with pooled TaqMan ${ }^{\circ}$ MicroRNA Assays (Applied Biosystems, Foster City, CA, USA) for miR-23b and RNU6B.

Real-time PCR for miR-23b quantification. The preamplified PCR product was diluted in DEPC water (1:20). Each sample was analysed in triplicate and the volume per each reaction was $10 \mu$ l. The reaction consisted of TaqMan ${ }^{\circ}$ Universal PCR Master Mix (2x) (Applied Biosystems, Foster City, CA, USA), DEPC water, corresponding TaqMan ${ }^{\circledR}$ MicroRNA Assay and diluted pre-amplified PCR product. Real-time PCR was performed using LightCycler ${ }^{\circledR} 480$ (Roche, Branford,
CT, USA) with appropriate software according to protocol and RNU6B was used as an endogenous control. The nontumor control sample was prepared by pooling commercially available Human Lung Total RNAs (AM7968, Lot. 0904002 and 1203010, Applied Biosystems, Foster City, CA, USA) and Total RNAs, Lung, Human (540019, Lot. 0006051745 and 0006079356, Agilent Technologies, Santa Clara, CA, USA). The relative expression level of miR-23b was calculated using the following equation: relative gene expression $=2^{-(\Delta \mathrm{Ct}}$ sample - $\Delta$ Ct control)

Statistical analysis. Statistical analysis was performed using software SPSS, version 20.0. Pearson's Chi-square was used to assess the relationships between categorical variables. MannWhitney test was used to evaluate difference between groups. Survival analysis was done by Kaplan-Meier method with the log-rank test applied for comparison of curves. Overall survival (OS) was defined as time from the surgery until patient's death, progression free survival (PFS) as time from surgery until disease relapse or patient's death. Cox proportional hazard model was created for assessing the risk of patient's death and/or relapse of disease. $\mathrm{P}<0.05$ was considered as statistically significant.

\section{Results}

TMA blocks from 62 patients were immunohistochemically analysed for P-gp, MRP and LRP/MVP expression. The tissues from TMAs were also used for the quantification of miR-23b expression.

Expression of P-gp, MRP and LRP/MVP in NSCLC. The expression of P-gp, MRP and LRP/MVP was assessed in 62 patients (Figures 1, 2). The P-gp was detected in $40(64.5 \%)$ patients, MRP in $50(80.6 \%)$ patients and expression of LRP/ MVP was found in 35 (56.4 \%) patients. Expression of these proteins in different histological subtypes is summarised in Table 2. There was no significant difference in P-gp, MRP or LRP/MVP expression between ADC, SCC and LCC specimens $\left(\mathrm{P}_{\mathrm{P}-\mathrm{gp}}=0.313, \mathrm{P}_{\text {MRP }}=0.432, \mathrm{P}_{\text {LRP } / \mathrm{MVP}}=0.108\right)$ (Figure 3). For the next analysis, very low expression of proteins was considered 


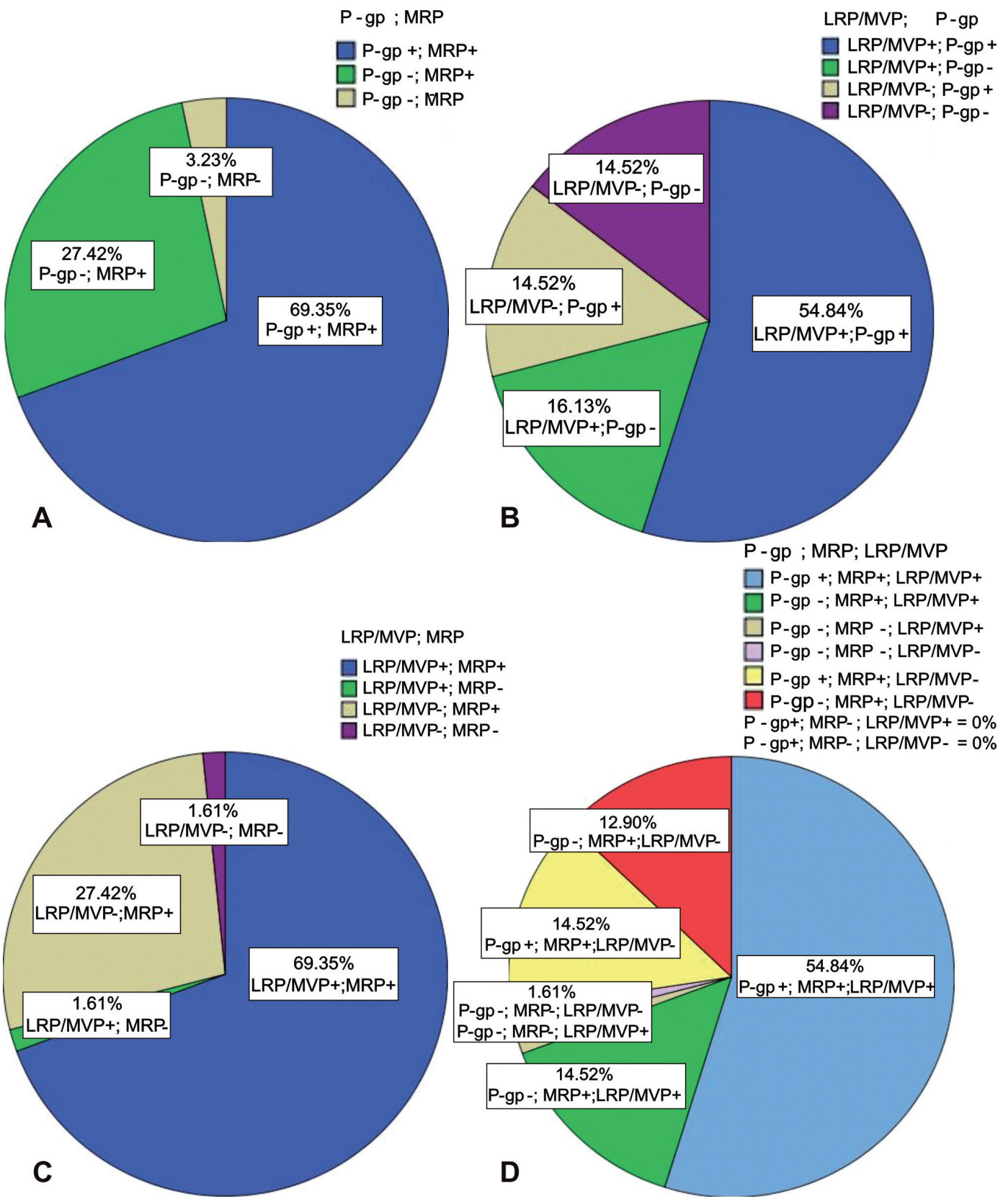

Figure 2. Combined expression of P-gp, MRP and LRP/MVP. Pie charts show percentage of combined expression of P-gp and MRP (A), LRP/MVP and P-gp (B), LRP/MVP and MRP (C) and all three analysed protein markers P-gp, MRP and LRP/MVP (D).

as a negative expression while low, moderate and high were considered as a positive expression.

Expression of miR-23b in NSCLC. The relative quantification of mature miR-23b in 62 lung cancer samples was performed. Higher expression of miR-23b compared to non-tumor control RNA was detected in 5 (8.1\%) samples and lower expression in 57 (91.9\%) samples. There was no significant difference in miR-23b expression between specimens from different histological subtypes (ADC, SCC, LCC;
$\mathrm{P}=0.711$; Table 3). For the next analysis, higher expression of miR-23b $\left(2^{-\Delta \Delta \mathrm{Ct}}>1\right)$ was marked as "up" (means upregulation) and lower expression $\left(2^{-\Delta \Delta \mathrm{Ct}}<1\right)$ was marked as "down" (means downregulation).

Relationship of miR-23b, P-gp, MRP and LRP/MVP expression with clinicopathological parameters. Progression free survival and overall survival were used as the clinicopathological parameters for evaluating the prognostic role of these variables in NSCLC patients. Patient outcome was monitored 


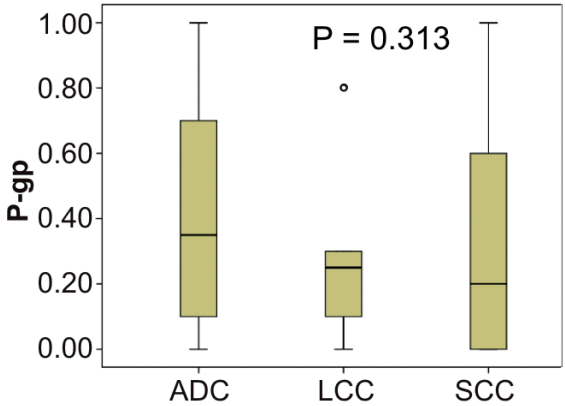

A Histological subtype

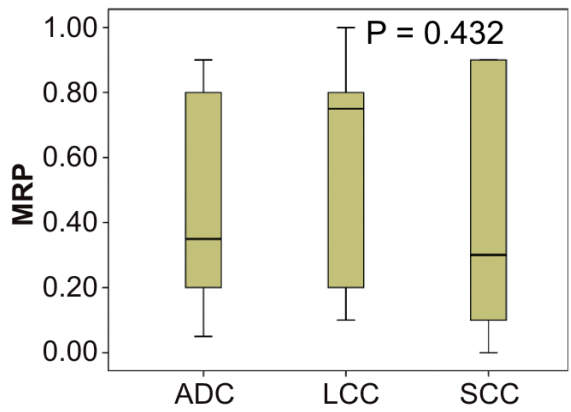

B

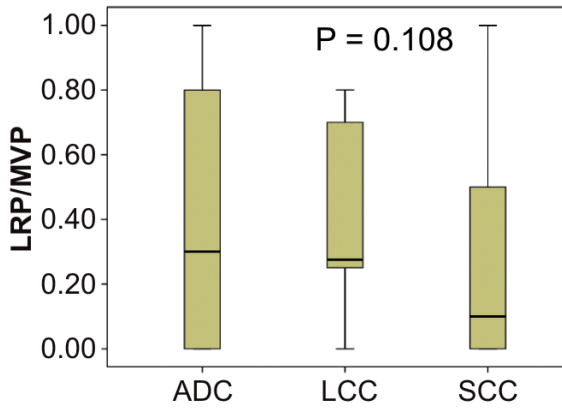

Histological subtype

Figure 3. Analysis of P-gp, MRP and LRP/MVP expression in different histological subtypes. Box plots show the proportion of P-gp (A), MRP (B) and LRP/MVP (C) expression in different histological subtypes of NSCLC.

ADC - adenocarcinoma, SCC - squamous cell carcinoma, LCC - large cell carcinoma.

Table 2. Summary of expression of P-gp, MRP and LRP/MVP in different histological subtypes.

\begin{tabular}{|c|c|c|c|c|c|c|c|}
\hline \multirow[b]{2}{*}{ Protein } & \multirow[b]{2}{*}{ Histological subtype } & \multicolumn{4}{|c|}{ Intensity } & \multicolumn{2}{|c|}{ Statistics } \\
\hline & & Very low $(\leq 0.1)$ & Low $(\leq 0.3)$ & Moderate $(\leq 0.6)$ & High $(>0.6)$ & Pearson $\chi^{2}$ & $\mathbf{P}$ \\
\hline \multirow{4}{*}{ P-gp } & $\mathrm{ADC}$ & 8 & 7 & 3 & 12 & \multirow{4}{*}{2.324} & \multirow{4}{*}{0.313} \\
\hline & SCC & 12 & 6 & 2 & 6 & & \\
\hline & LCC & 2 & 3 & 0 & 1 & & \\
\hline & Total [No. (\%)] & $22(35.5)$ & $16(25.8)$ & $5(8.1)$ & $19(30.6)$ & & \\
\hline \multirow{4}{*}{ MRP } & $\mathrm{ADC}$ & 4 & 11 & 4 & 11 & \multirow{4}{*}{1.679} & \multirow{4}{*}{0.432} \\
\hline & SCC & 7 & 7 & 1 & 11 & & \\
\hline & LCC & 1 & 1 & 0 & 4 & & \\
\hline & Total [No. (\%)] & $12(19.4)$ & $19(30.6)$ & $5(8.1)$ & $26(41.9)$ & & \\
\hline \multirow{4}{*}{ LRP/MVP } & $\mathrm{ADC}$ & 11 & 4 & 3 & 12 & \multirow{4}{*}{4.457} & \multirow{4}{*}{0.108} \\
\hline & SCC & 15 & 2 & 5 & 4 & & \\
\hline & LCC & 1 & 3 & 0 & 2 & & \\
\hline & Total [No. (\%)] & $27(43.5)$ & $9(14.5)$ & $8(12.9)$ & $18(29.0)$ & & \\
\hline
\end{tabular}

Comparison of negative $(\leq 0.1)$ and positive $(\geq 0.1)$ expression of MDR proteins in different histological subtypes. MDR - multidrug resistance, $\mathrm{P}$-gp - Pglycoprotein, MRP - Multidrug resistance-related protein 1, LRP/MVP - Lung-resistance related protein/Major vault protein, ADC - adenocarcinoma, SCC - squamous cell carcinoma, LCC - large cell carcinoma.

over 175 months. Individual data are showed in Table 4. Expression of P-gp, MRP and LRP/MVP in patients with regard to miR-23b expression levels is summarised in Table 5. The Kaplan-Meier analysis showed a trend to association between PFS $(P=0.065)$ and statistically significant relationship be-

Table 3. Expression of miR-23b in different histological subtypes.

\begin{tabular}{cccc}
\hline & \multicolumn{2}{c}{ miR-23b } & Total \\
\cline { 2 - 3 } Histological subtype & down & up & \\
\hline ADC & 27 & 3 & 30 \\
SCC & 24 & 2 & 26 \\
LCC & 6 & 0 & 6 \\
Total & 57 & 5 & 62 \\
\hline
\end{tabular}

Summary of miR-23b relative expression in different histological subtypes based on $2^{-\Delta \Delta C t}$ values.

Down - downregulation $\left(2^{-\Delta \Delta C t}<1\right)$, up - upregulation $\left(2^{-\Delta \Delta C t}>1\right)$. tween OS $(\mathrm{P}=0.048)$ and miR-23b expression (Figure 4A, B). Survival analysis showed no significant association between expression of P-gp, MRP and LRP/MVP and patient's outcome (P-gp: $\mathrm{P}_{\mathrm{PFS}}=0.993, \mathrm{P}_{\mathrm{OS}}=0.982 ; \mathrm{MRP}: \mathrm{P}_{\mathrm{PFS}}=0.911, \mathrm{P}_{\mathrm{OS}}=0.945$; LRP/MVP: $\mathrm{P}_{\mathrm{PES}}=0.908, \mathrm{P}_{\mathrm{OS}}=0.966$; Figure 4C-H). Based on these results, overexpression of miR-23b seems to be good prognostic factor in the case of NSCLC patients.

Cox regression hazard model. The relationship between miR-23b and P-gp, MRP and LRP/MVP was first analysed by Chi-Square and Mann-Whitney tests. Neither of them showed any significant association between the variables (Table 6).

The Cox proportional hazard model was created to assess the relationship between the risk of death or relapse and variables of interest such as miR-23b and LRP/MVP. The association between the risk and the above variables were statistically significant (PFS: $\mathrm{P}=0.022, \mathrm{HR}=4.342, \mathrm{CI}(95 \%)$ $=1.231-15.318$, Wald $=5.211 ;$ OS: $\mathrm{P}=0.015, \mathrm{HR}=4.408, \mathrm{CI}$ $(95 \%)=1.356-16.350$, Wald $=5.949)$ and model fit parameters 
Table 4. Individual data on tumor classification and expression levels of analysed markers.

\begin{tabular}{|c|c|c|c|c|c|c|c|c|c|}
\hline \multirow{2}{*}{ Patient No. } & \multirow{2}{*}{ Gender } & \multirow{2}{*}{ Histological subtype } & \multicolumn{3}{|c|}{ Classification } & \multirow{2}{*}{ P-gp } & \multirow{2}{*}{ MRP } & \multirow{2}{*}{ LRP/MVP } & \multirow{2}{*}{ miR-23b } \\
\hline & & & $\mathrm{T}$ & $\mathbf{N}$ & M & & & & \\
\hline 1 & $\mathrm{M}$ & ADC & & & & 0.0 & 0.9 & 0.0 & 0.00 \\
\hline 3 & M & SCC & 2 & 2 & 0 & 0.0 & 0.0 & 0.0 & 0.00 \\
\hline 4 & M & LCC & 2 & 0 & 0 & 0.1 & 0.8 & 0.1 & 0.17 \\
\hline 5 & M & $\mathrm{ADC}$ & 1 & 0 & 0 & 0.3 & 0.9 & 0.2 & 0.18 \\
\hline 6 & M & $\mathrm{ADC}$ & 2 & 0 & 0 & 0.0 & 0.9 & 0.7 & 0.09 \\
\hline 7 & M & $\mathrm{ADC}$ & 1 & 0 & 0 & 0.3 & 0.8 & 0.1 & 0.09 \\
\hline 8 & $\mathrm{~F}$ & SCC & 3 & 2 & 0 & 0.6 & 0.3 & 0.9 & 0.56 \\
\hline 9 & M & SCC & 3 & 1 & 0 & 0.0 & 0.1 & 0.5 & 1.73 \\
\hline 10 & M & SCC & & & & 0.3 & 0.9 & 0.0 & 0.00 \\
\hline 11 & M & SCC & 2 & 0 & 0 & 0.0 & 0.9 & 1.0 & 0.00 \\
\hline 12 & M & $\mathrm{ADC}$ & 2 & 0 & 0 & 0.0 & 0.6 & 0.0 & 0.04 \\
\hline 13 & M & SCC & 2 & 2 & 0 & 0.6 & 0.1 & 0.0 & 0.07 \\
\hline 14 & M & SCC & 1 & 0 & 0 & 0.0 & 0.9 & 0.0 & 0.01 \\
\hline 15 & M & $\mathrm{ADC}$ & 4 & 2 & 0 & 0.3 & 0.2 & 0.7 & 0.15 \\
\hline 16 & M & $\mathrm{ADC}$ & 2 & 2 & 0 & 1.0 & 0.3 & 1.0 & 0.06 \\
\hline 17 & M & $\mathrm{ADC}$ & 3 & 2 & 0 & 0.0 & 0.2 & 1.0 & 0.36 \\
\hline 19 & $\mathrm{M}$ & SCC & 3 & 1 & 0 & 0.0 & 0.3 & 0.0 & 0.15 \\
\hline 20 & $\mathrm{M}$ & SCC & & & & 0.0 & 0.8 & 0.0 & 0.05 \\
\hline 21 & $\mathrm{M}$ & SCC & 2 & 0 & 0 & 0.0 & 0.8 & 0.4 & 0.04 \\
\hline 22 & M & SCC & 2 & 2 & 0 & 0.0 & 0.0 & 0.1 & 0.03 \\
\hline 23 & $\mathrm{M}$ & SCC & & & & 0.0 & 0.9 & 0.0 & 0.11 \\
\hline 24 & $\mathrm{M}$ & $\mathrm{ADC}$ & 1 & 0 & 0 & 0.0 & 0.8 & 0.0 & 3.38 \\
\hline 25 & $\mathrm{~F}$ & $\mathrm{ADC}$ & 4 & 2 & 1 & 0.8 & 0.1 & 0.2 & 0.09 \\
\hline 26 & $\mathrm{M}$ & $\mathrm{ADC}$ & 2 & 0 & 1 & 0.0 & 0.3 & 1.0 & 0.23 \\
\hline 27 & $\mathrm{M}$ & SCC & 4 & 0 & 0 & 0.0 & 0.1 & 0.5 & 0.14 \\
\hline 28 & M & $\mathrm{ADC}$ & 3 & 2 & 1 & 0.8 & 0.2 & 0.5 & 0.13 \\
\hline 29 & M & $\mathrm{ADC}$ & & & & 0.2 & 0.8 & 0.0 & 0.15 \\
\hline 30 & $\mathrm{~F}$ & $\mathrm{ADC}$ & 2 & 2 & 0 & 0.7 & 0.2 & 0.0 & 0.15 \\
\hline 31 & M & $\mathrm{ADC}$ & & & & 1.0 & 0.8 & 0.9 & 0.17 \\
\hline 32 & M & $\mathrm{ADC}$ & 1 & 0 & 0 & 0.1 & 0.8 & 0.2 & 0.04 \\
\hline 33 & $\mathrm{M}$ & LCC & 2 & 1 & 0 & 0.2 & 1.0 & 0.3 & 0.10 \\
\hline 34 & $\mathrm{M}$ & SCC & 2 & 2 & 0 & 0.0 & 0.1 & 0.0 & 0.18 \\
\hline 35 & M & SCC & 2 & 1 & 0 & 0.3 & 0.9 & 0.0 & 0.26 \\
\hline 36 & M & SCC & 3 & 1 & 0 & 1.0 & 0.2 & 0.8 & 0.24 \\
\hline 37 & M & ADC & 2 & 2 & 0 & 0.3 & 0.2 & 0.9 & 0.03 \\
\hline 38 & $\mathrm{M}$ & SCC & 2 & 2 & 0 & 0.7 & 0.3 & 0.0 & 0.15 \\
\hline 39 & M & LCC & 1 & 2 & 0 & 0.3 & 0.1 & 0.8 & 0.49 \\
\hline 40 & $\mathrm{M}$ & LCC & 1 & 1 & 0 & 0.0 & 0.7 & 0.7 & 0.25 \\
\hline 41 & $\mathrm{M}$ & SCC & 2 & 2 & 0 & 0.0 & 0.2 & 0.1 & 0.05 \\
\hline 42 & $\mathrm{~F}$ & $\mathrm{ADC}$ & 1 & 0 & 0 & 0.4 & 0.9 & 0.1 & 0.27 \\
\hline 43 & $\mathrm{M}$ & $\mathrm{ADC}$ & 4 & 1 & 0 & 0.9 & 0.4 & 0.8 & 21.95 \\
\hline 44 & $\mathrm{M}$ & $\mathrm{ADC}$ & 2 & 2 & 0 & 0.9 & 0.1 & 0.0 & 0.97 \\
\hline 45 & F & $\mathrm{ADC}$ & & & & 0.1 & 0.9 & 0.4 & 0.11 \\
\hline 46 & $\mathrm{~F}$ & SCC & 3 & 1 & 0 & 0.8 & 0.3 & 1.0 & 0.50 \\
\hline 47 & $\mathrm{M}$ & $\mathrm{ADC}$ & 2 & 1 & 0 & 0.2 & 0.8 & 0.1 & 0.23 \\
\hline 48 & $\mathrm{M}$ & SCC & 1 & 0 & 0 & 0.2 & 0.9 & 0.5 & 0.31 \\
\hline 49 & $\mathrm{~F}$ & $\mathrm{ADC}$ & 4 & 2 & 0 & 0.7 & 0.2 & 0.0 & 0.06 \\
\hline 50 & M & $\mathrm{ADC}$ & 1 & 0 & 1 & 0.7 & 0.1 & 0.2 & 0.39 \\
\hline 51 & $\mathrm{M}$ & SCC & 1 & 2 & 0 & 0.8 & 0.3 & 0.6 & 0.28 \\
\hline 52 & $\mathrm{M}$ & SCC & & & & 0.2 & 0.8 & 0.1 & 0.20 \\
\hline 53 & M & $\mathrm{ADC}$ & 1 & 0 & 0 & 0.5 & 0.6 & 0.4 & 0.22 \\
\hline 54 & $\mathrm{M}$ & $\mathrm{ADC}$ & 3 & 1 & 0 & 0.7 & 0.3 & 0.8 & 1.26 \\
\hline 55 & $\mathrm{M}$ & SCC & 2 & 0 & 1 & 0.8 & 0.1 & 1.0 & 5.15 \\
\hline 56 & M & $\mathrm{ADC}$ & $\mathrm{x}$ & 3 & 1 & 0.6 & 0.1 & 0.7 & 0.18 \\
\hline 57 & M & $\mathrm{ADC}$ & 1 & 0 & 1 & 0.7 & 0.2 & 0.0 & 0.57 \\
\hline 59 & $\mathrm{M}$ & $\mathrm{ADC}$ & 3 & 0 & 0 & 0.3 & 0.6 & 0.8 & 0.25 \\
\hline 60 & M & LCC & 3 & 3 & 0 & 0.8 & 0.2 & 0.3 & 0.16 \\
\hline 61 & $\mathrm{M}$ & $\mathrm{ADC}$ & 3 & 2 & 0 & 0.8 & 0.2 & 0.7 & 0.68 \\
\hline 62 & M & LCC & & & & 0.3 & 0.8 & 0.3 & 0.16 \\
\hline 63 & $\mathrm{M}$ & SCC & 3 & 2 & 2 & 0.9 & 0.4 & 1.0 & 0.55 \\
\hline 65 & $\mathrm{M}$ & SCC & & & & 0.3 & 0.8 & 0.3 & 0.27 \\
\hline 66 & M & SCC & & & & 0.2 & 0.9 & 0.2 & 0.24 \\
\hline
\end{tabular}

Individual data of 62 patients on gender, histological subtype, TNM classification and expression levels of analysed markers. Expression level of protein markers $\mathrm{P}$-gp, MRP and LRP/MVP is showed as percentage of positive cells ( $0.0 \mathrm{~min}-1.0 \mathrm{max})$. Relative expression of miR-23b is showed as $2^{-\Delta \Delta C t}$ value. Value $2^{-\Delta \Delta \mathrm{Ct}}$ $>1$ means upregulation and $2^{-\Delta \Delta \mathrm{Ct}}<1$ means downregulation of miR-23b. $\mathrm{M}-$ man, $\mathrm{F}-$ female. 


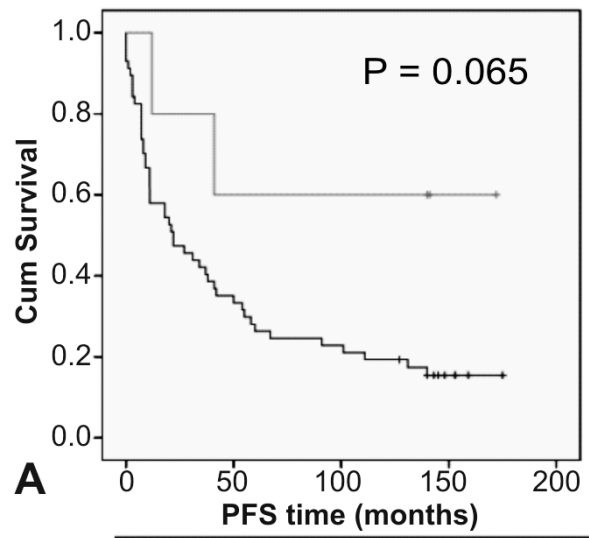

miR-23b
- down
+ up
+ down-censored
+ up-censored
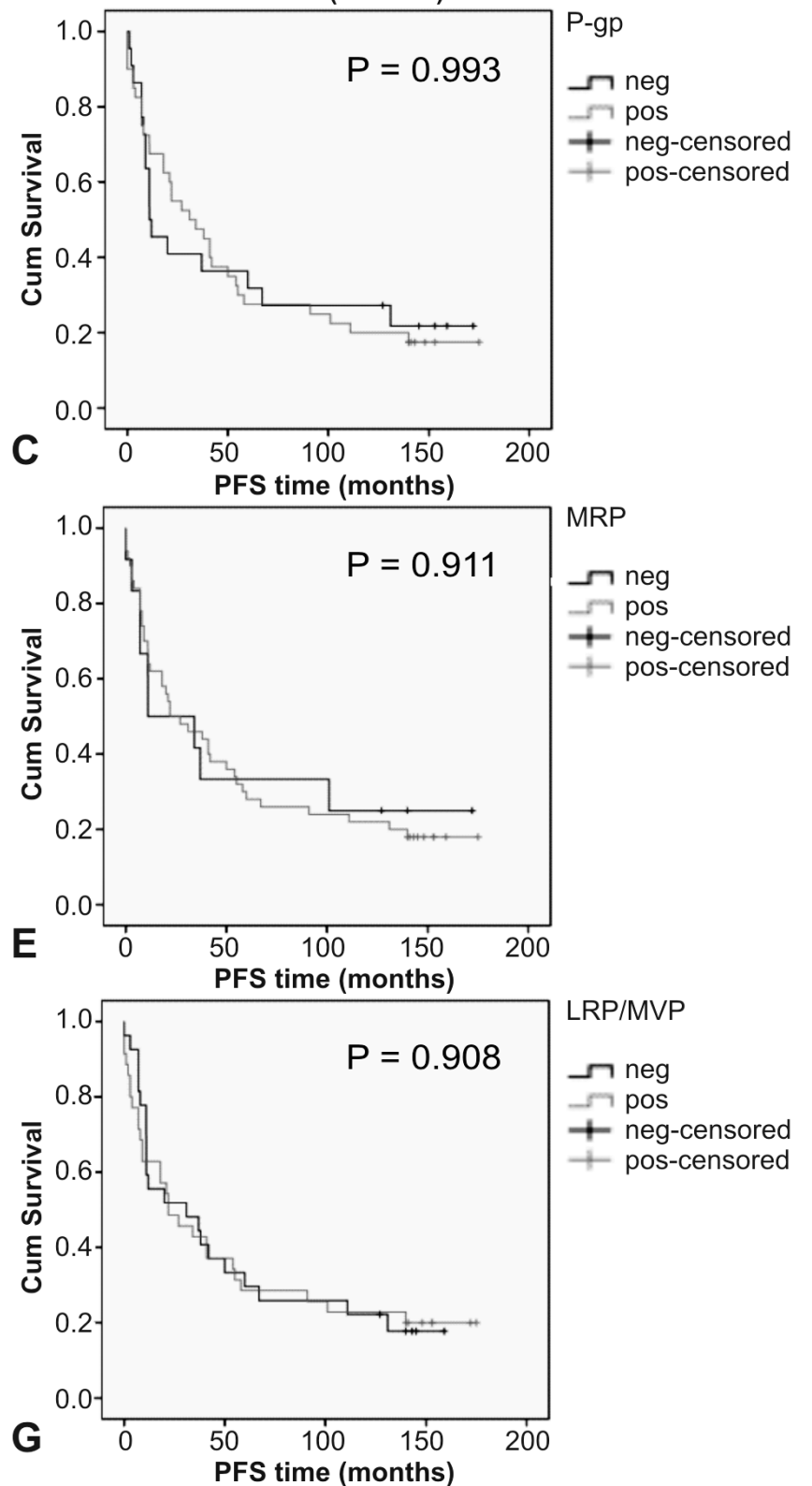
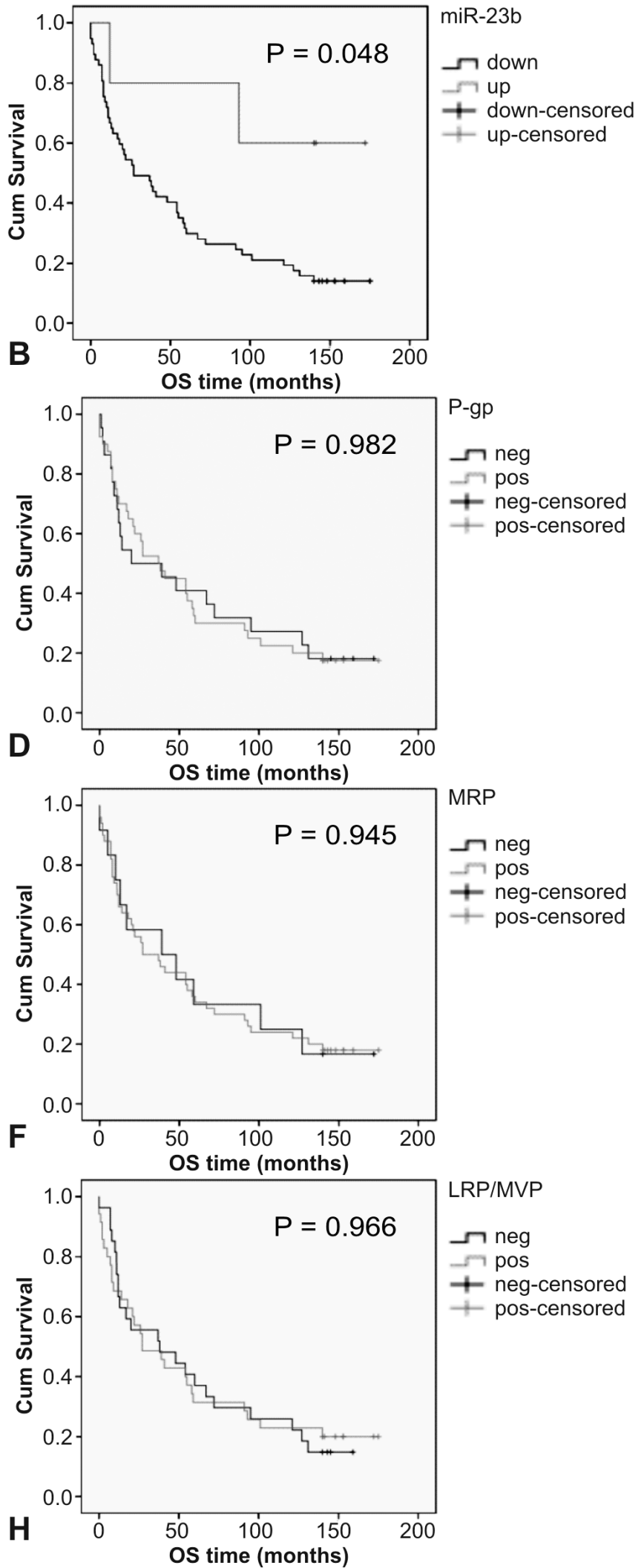

Figure 4. Survival analysis of miR-23b, P-gp, MRP and LRP/MVP in NSCLC patients. Kaplan-Meier curves represent PFS and OS of NSCLC patients and depend on the expression of miR-23b (A, B), P-gp (C, D), MRP (E, F) and LRP/MVP (G, H). PFS - progression-free survival, OS - overall survival. 
meet the required criteria (PFS: $\mathrm{P}=0.020, \chi^{2}=5.400$; OS: $\mathrm{P}=$ $\left.0.013, \chi^{2}=6.185\right)$. As a result, there was increased risk of death or relapse in patients with miR-23b downregulation and LRP/ MVP expression from 0.1 to 1 ; and there was decreased risk of death or relapse in patients who had upregulated miR-23b (Figure 5). Association between risks and miR-23b with P-gp and MRP expression was not significant for modelling. Importantly, univariate Cox regression analysis of miR-23b indicated that there was a trend of association between miR-23b and risk of death or relapse in NSCLC patients (PFS: $\mathrm{P}=0.087, \mathrm{HR}=$ 3.451 , CI $(95 \%)=0.836-14.246$, Wald $=2.932$; OS: $\mathrm{P}=0.067$, $\mathrm{HR}=3.765$, CI $(95 \%)=0.912-15.552$, Wald $=3.357)$. Therefore, the combined model of miR-23b and LRP/MVP defines well the risk of death or relapse in NSCLC patients.

We also found that patients expressing P-gp from 0.1 to 1 with miR-23b downregulation had higher risk of cancerrelated death compared to patients with miR-23b upregulation $\left(\mathrm{RR}=2.595, \mathrm{CI}=0.521-12.920, \chi^{2}=5.430, \mathrm{P}=0.02\right.$; Figure 6). However, as mentioned above, combined expression of miR$23 \mathrm{~b}$ with P-gp did not meet the criteria for modelling and no Cox regression model for these variables was prepared.

Our results showed that miR-23b, especially in combination with LRP/MVP, may serve as a prognostic biomarker for NSCLC patients. A larger cohort of patient samples is needed to be analyzed to confirm the results.

\section{Discussion}

The initial goal of this preliminary study was to determine the significance of miR-23b in NSCLC. Previous studies describe its dual role as an oncogenic or tumor-suppressor miRNA depending on cancer type [25]. The relative quantification of miR-23b in this study showed that miR-23b is mostly downregulated in NSCLC patient samples (57 out of 62 samples). Its downregulation has also been described in prostate, bladder and thyroid cancer. Higher levels of miR$23 \mathrm{~b}$ are a good prognostic factor according to some authors $[26,28,32]$. The survival analysis data are in agreement with these studies showing that upregulation of miR-23b in tumors with its predominant downregulation is connected with better patient outcome $\left(\mathrm{P}_{\mathrm{PFS}}=0.065 ; \mathrm{P}_{\mathrm{OS}}=0.048\right)$. There are also studies that present miR-23b as an oncogenic miRNA, where its upregulation in different tumors is associated with worse patient outcome [29-31]. The split role of miR-23b in different cancer types can be caused by targeting different molecules.

Table 5. Summary of expression of P-gp, MRP and LRP/MVP in patients with regard to miR-23b up- and downregulation.

\begin{tabular}{llllllll}
\hline & & P-gp & \multicolumn{3}{c}{ MRP } & \multicolumn{2}{c}{ LRP/MVP } \\
\cline { 3 - 7 } & & negat & posit & negat & posit & negat & posit \\
\hline \multirow{2}{*}{ miR-23b } & down & 20 & 37 & 10 & 47 & 26 & 31 \\
& up & 2 & 3 & 2 & 3 & 1 & 4 \\
\hline Total & & 22 & 40 & 12 & 50 & 27 & 35 \\
\hline
\end{tabular}

In tumors with miR-23b predominant downregulation it is known as a tumor-suppressor and targets mainly proteins responsible for proliferation and metastasis formation, such as AKT, Src kinase, ZEB1 or SNAIL [26-28]. In tumors with miR-23b upregulation, it functions as an oncogene and targets mainly proteins involved in apoptosis and metastasis suppression, such as Nischarin, VHL or PTEN [29-31].

Park et al. identified participation of miR-23b in chemoresistance [35]. Therefore, we decided to detect immunohistochemical expression of well-known proteins associated with MDR, namely P-gp, MRP and LRP/MVP. Expression of P-gp was detected in 40 (64.5\%), MRP in 50 (80.6 \%) and LRP/MVP in 35 (56.4 \%) patients. Our survival analysis showed no relationship between expression of these proteins and PFS and OS (P-gp: $\mathrm{P}_{\mathrm{PFS}}=0.993, \mathrm{P}_{\mathrm{OS}}$ $=0.982 ;$ MRP: $\mathrm{P}_{\mathrm{PFS}}=0.911, \mathrm{P}_{\mathrm{OS}}=0.945 ; \mathrm{LRP} / \mathrm{MVP}: \mathrm{P}_{\mathrm{PFS}}=$ $0.908, \mathrm{P}_{\text {OS }}=0.966$ ). Similar observations were also published by other authors [36-39]. On the other hand, there are also studies supporting the negative prognostic role of these MDR proteins in cancer patients [40-44]. Thus, we decided to establish Cox proportional hazard model for testing the possible prognostic significance of combined expression of these proteins and miR-23b and for assessing risk of death and relapse in our patients.

First, we found that patients expressing P-gp with miR23b downregulation had higher risk of cancer-related death compared to patients with miR-23b upregulation $(\mathrm{RR}=$ $2.595, \mathrm{P}=0.02)$. More importantly, our Cox proportional hazard model showed that the risk of death or relapse in patients with miR-23b downregulation increases together with expression of LRP/MVP and decreases in patients with miR-23b upregulation (PFS: $\mathrm{P}=0.022, \mathrm{HR}=4.342$; OS: $\mathrm{P}=$ $0.015, \mathrm{HR}=4.408)$. On the other hand, univariate analysis of miR-23b alone did not show any statistically significant association with patient's risk ( $\mathrm{PFS}: \mathrm{P}=0.087, \mathrm{HR}=3.451$; OS: $\mathrm{P}=0.067, \mathrm{HR}=3.765)$. We are probably the first group interested in the prognostic role of miR-23b in combination with other known biomarkers in NSCLC. But available reports on the possible role of miR-23b in different cancer types support our observations. These authors found that miR-23b upregulation is associated with better patient's prognosis in tumors where it occurs as a tumor-suppressor $[26,28]$. These preliminary results need to be validated in a larger cohort of cases.

Table 6. Correlation analysis of expression of miR-23b and P-gp, MRP and LRP/MVP.

\begin{tabular}{cccccc}
\hline \multirow{7}{*}{ Protein } & \multicolumn{2}{c}{ Chi-Square test } & \multicolumn{2}{c}{ Mann-Whitney test } \\
\cline { 3 - 6 } & & $\boldsymbol{\chi}^{2}$ value & $\mathbf{P}$ & $\mathbf{P}$ & $\mathbf{Z}$ \\
\cline { 2 - 6 } miR-23b & P-gp & 0.048 & 0.826 & 0.599 & -0.526 \\
& MRP & 1.485 & 0.223 & 0.320 & 0.995 \\
& LRP/MVP & 1.227 & 0.268 & 0.115 & -1.576 \\
\hline
\end{tabular}

The relationship between miR-23b and P-gp, MRP and LRP/MVP analysed by Chi-Square and Mann-Whitney tests. 


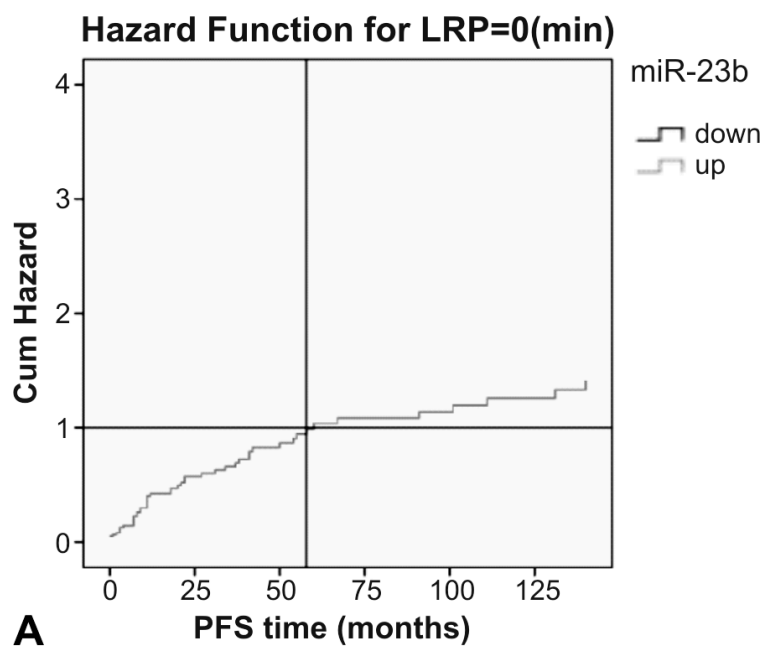

\section{Hazard Function for LRP $=0.2$ (med)}

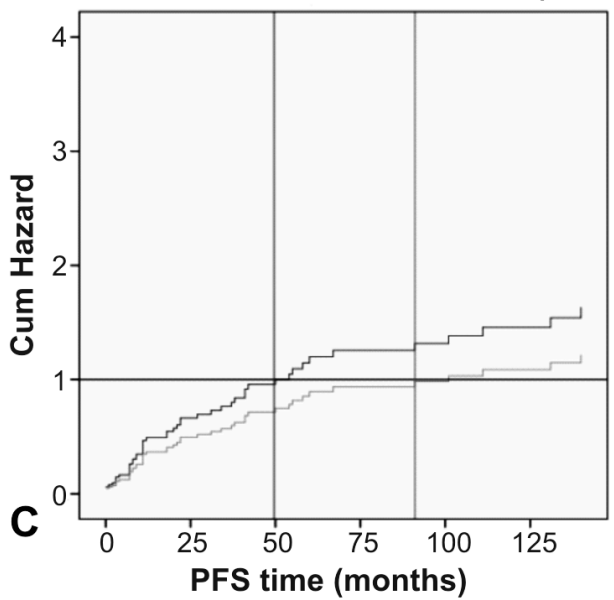

miR-23b

$\rightarrow$ down
$\rightarrow$ up

B

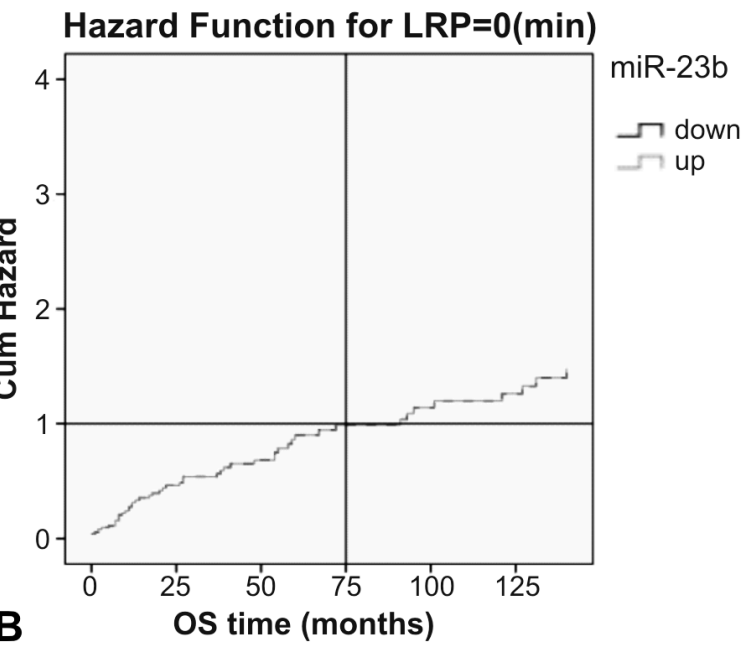

Hazard Function for LRP $=0.2$ (med)

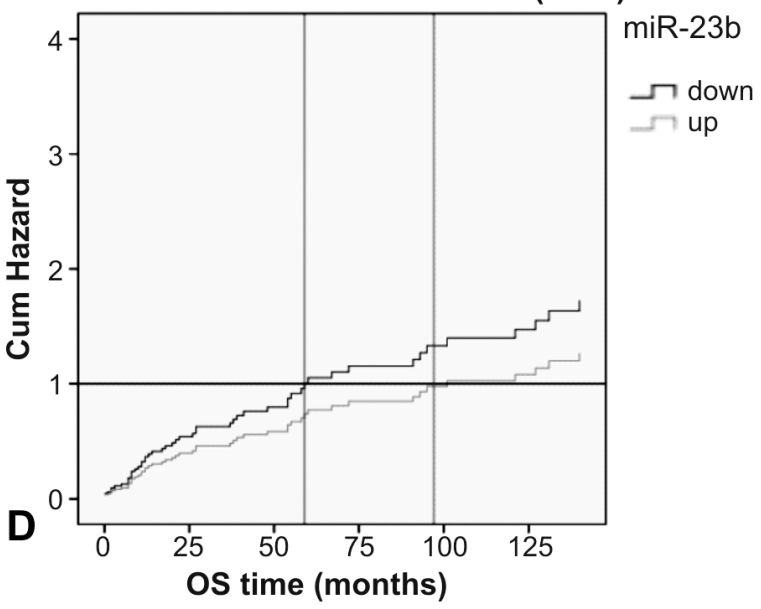

Hazard Function for $L R P=1$ ( $\max )$
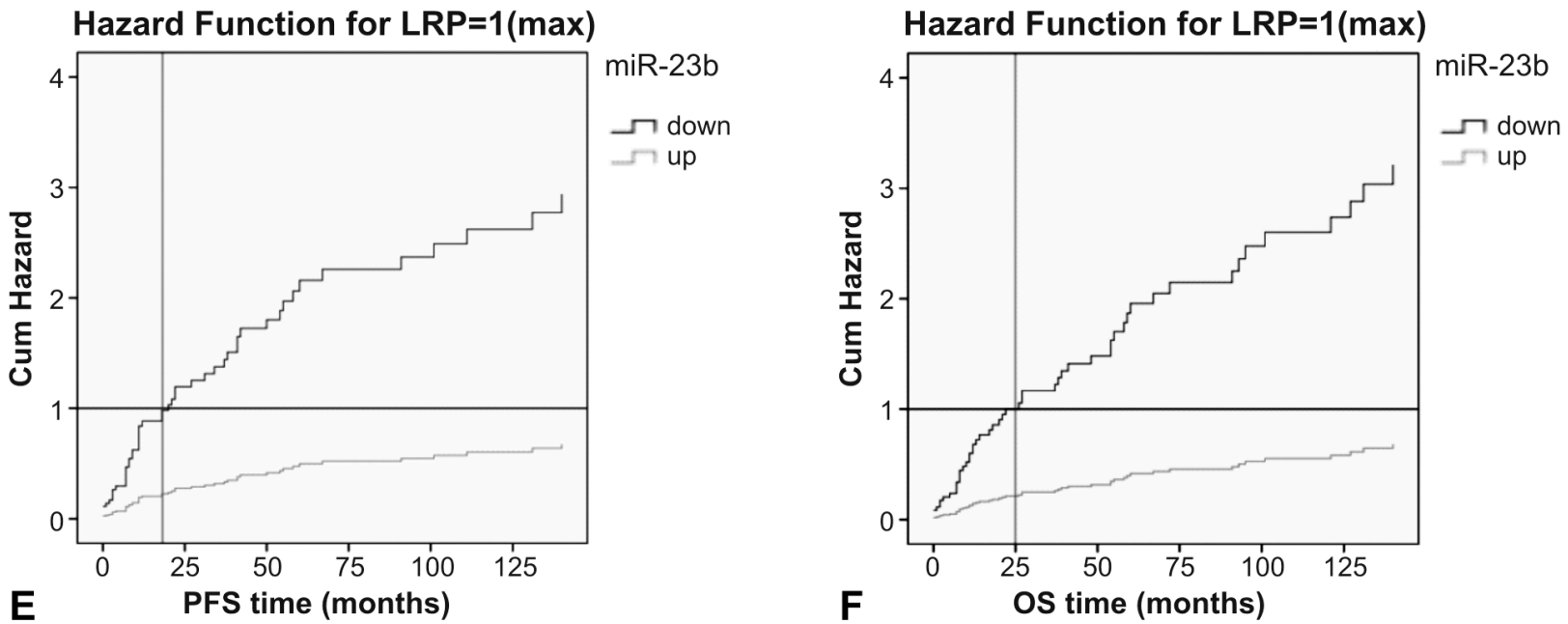

Figure 5. Cox regression hazard model of miR-23b and LRP/MVP expression in NSCLC patients. Hazards of death and relapse between miR-23b downand upregulation groups are the same when LRP/MVP expression is $0(\mathrm{~A}, \mathrm{~B})$. Hazard is higher in the group with miR-23b downregulation in comparison to the group with miR-23b upregulation when LRP/MVP expression is 0.2 (median) (C, D). The difference between the hazards of miR-23b down- and upregulation groups is the highest when LRP/MVP expression is $1(\mathrm{max})(\mathrm{E}, \mathrm{F})$. 
Pgp: neg

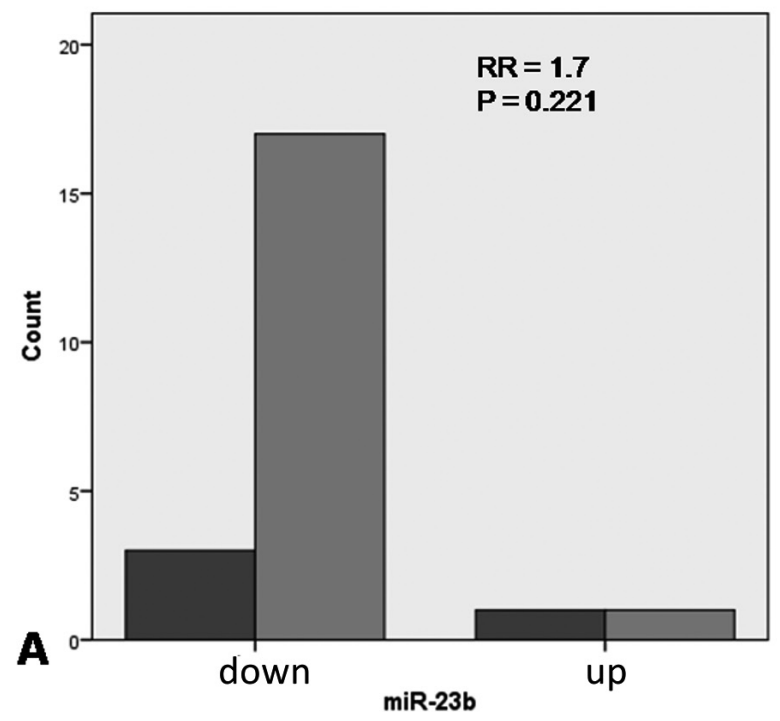

Pgp: pos

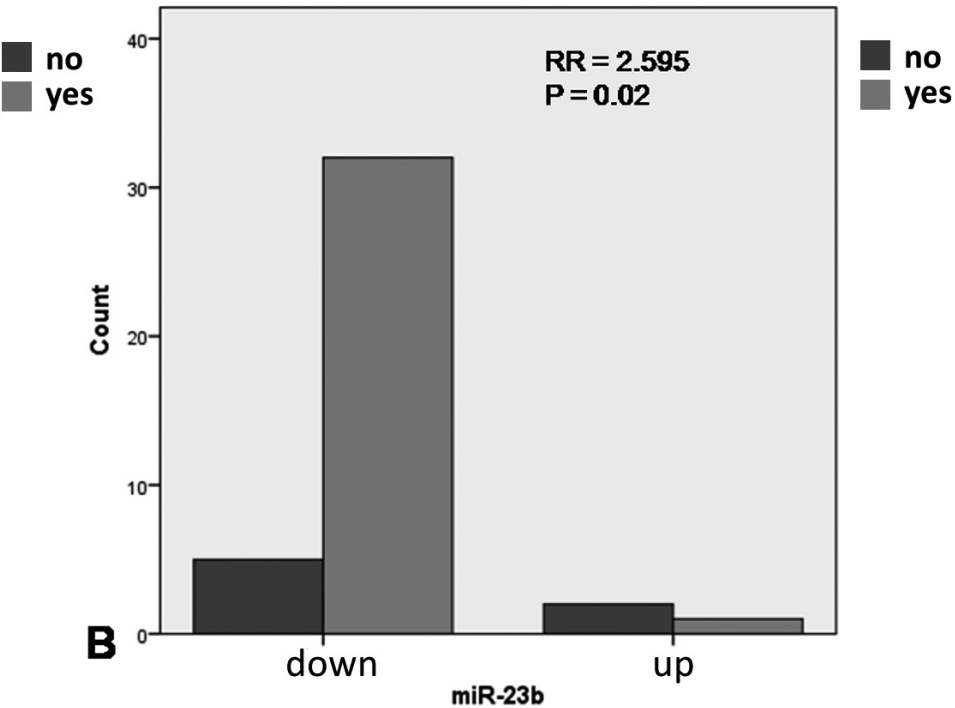

Figure 6. Odds ratio of P-gp and miR-23b expression in NSCLC patients. Patients with miR-23b downregulation had higher risk of cancer-related death compared to patients with miR-23b upregulation in the case of P-gp expression from 0.1 to 1.

\section{Conclusion}

In this study, we determined the possible role of miR-23b which is very often deregulated in different cancers and its role in NSCLC has not been fully established yet. The results suggest that miR-23b may function as a tumor-suppressor in NSCLC as it was often downregulated in advanced tumors and patients had better outcome when it was upregulated. Our results also showed that detection of miR-23b levels together with P-gp and LRP/MVP expression may be suitable for assessing the prognosis and risk in NSCLC patients. According to the regression model, the risk of death or relapse in NSCLC patients with downregulated miR-23b increases together with LRP/MVP expression and decreases in patients with upregulated miR-23b.

Acknowledgements: We would like to thank Jiri Klein and Vitezslav Kolek for kind help with collection and characterization of patients. We would like to thank also Eva Sedlakova for the performance of immunohistochemical staining. This work was supported by grants: IGA MZCR NT13569, LF_2014_003 and NPU I LO1304.

\section{References}

[1] D'ADDARIO G, FRUH M, RECK M, BAUMANN P, KLEPETKO W et al. ESMO Guidelines Working Group: Metastatic non-small-cell lung cancer: ESMO Clinical Practice Guidelines for diagnosis, treatment and follow-up. Ann Oncol 2010; 21(Suppl 5): v116-v119. http://dx.doi.org/10.1093/annonc/mdq189

[2] KARTNER N, RIORDAN JR, LING V Cell surface P-glycoprotein associated with multidrug resistance in mammalian cell lines. Science 1983; 221: 1285-1288. http://dx.doi.org/10.1126/ science.6137059

[3] COLE SP, BHARDWAJ G, GERLACH JH, MACKIE JE, GRANT CE et al. Overexpression of a transporter gene in a multidrug-resistant human lung cancer cell line. Science 1992; 258: 1650-1654. http://dx.doi.org/10.1126/science.1360704

[4] COLE SP, DEELEY RG Transport of glutathione and glutathione conjugates by MRP1. Trends Pharmacol Sci 2006; 27: 438-446. http://dx.doi.org/10.1016/j.tips.2006.06.008

[5] NOSKOVA V, HAJDUCH M, MIHAL V, CWIERTKA K [Mechanisms of multidrug resistance and their clinical implications, I. typical MDR]. Klin Onkol 2000; 13: 4-9. [Article in Czech]

[6] DEAN M, RZHETSKY A, ALLIKMETS R The human ATPbinding cassette $(\mathrm{ABC})$ transporter superfamily. Genome Res 2001; 11: 1156-1166. http://dx.doi.org/10.1101/gr.GR$\underline{1649 \mathrm{R}}$

[7] FOJO AT, UEDA K, SLAMON DJ, POPLACK DG, GOTTESMAN MM et al. Expression of a multidrug-resistance gene in human tumors and tissues. Proc Natl Acad Sci U S A 1987; 84: 265-269. http://dx.doi.org/10.1073/pnas.84.1.265

[8] FLENS MJ, ZAMAN GJ, VAN DER VALK P, IZQUIERDO MA, SCHROEIJERS AB et al. Tissue distribution of the multidrug resistance protein. Am J Pathol 1996; 148: 1237-1247.

[9] DEMEULE M, REGINA A, JODOIN J, LAPLANTE A, DAGENAIS C et al. Drug transport to the brain: key roles for the efflux pump P-glycoprotein in the blood-brain barrier. Vascul Pharmacol 2002; 38: 339-348. http://dx.doi.org/10.1016/ $\underline{\text { S1537-1891(02)00201-X }}$

[10] NIES AT, JEDLITSCHKY G, KONIG J, HEROLD-MENDE $\mathrm{C}$, STEINER HH et al. Expression and immunolocalization of the multidrug resistance proteins, MRP1-MRP6 (ABCC1- 
ABCC6), in human brain. Neuroscience 2004; 129: 349-360. http://dx.doi.org/10.1016/j.neuroscience.2004.07.051

[11] NOOTER K, BOSMAN FT, BURGER H, VAN WINGERDEN KE, FLENS MJ et al. Expression of the multidrug resistanceassociated protein (MRP) gene in primary non-small-cell lung cancer. Ann Oncol 1996; 7: 75-81. http://dx.doi.org/10.1093/ oxfordjournals.annonc.a010484

[12] Burger H, Nooter K, ZAMAN GJ, SONNEVELD P, VAN WINGERDEN KE et al. Expression of the multidrug resistance-associated protein (MRP) in acute and chronic leukemias. Leukemia 1994; 8: 990-997.

[13] SCHEFFER GL, WIJNGAARD PL, FLENS MJ, IZQUIERDO MA, SLOVAK ML et al. The drug resistance-related protein LRP is the human major vault protein. Nat Med 1995; 1: 578-582. http://dx.doi.org/10.1038/nm0695-578

[14] KICKHOEFER VA, RAJAVEL KS, SCHEFFER GL, DALTON WS, SCHEPER RJ et al. Vaults are up-regulated in multidrugresistant cancer cell lines. J Biol Chem 1998; 273: 8971-8974. http://dx.doi.org/10.1074/jbc.273.15.8971

[15] KEDERSHA NL, ROME LH Isolation and characterization of a novel ribonucleoprotein particle: large structures contain a single species of small RNA. J Cell Biol 1986; 103: 699-709. http://dx.doi.org/10.1083/jcb.103.3.699

[16] IZQUIERDO MA, SCHEFFER GL, FLENS MJ, GIACCONE G, BROXTERMAN HJ et al. Broad distribution of the multidrug resistance-related vault lung resistance protein in normal human tissues and tumors. Am J Pathol 1996; 148: 877-887.

[17] VENTURA A, KUMAR MS, JACKS T Roles of microRNAs in cancer and development. In: Appasani K, editor. MicroRNAs: From Basic Science to Disease Biology. New York: Cambridge University Press, 2008: 322-337.

[18] O'CONNELL RM, BALTIMORE D MicroRNAs and hematopoietic cell development. Curr Top Dev Biol 2012; 99: 145-174. http://dx.doi.org/10.1016/B978-0-12-3870384.00006-9

[19] MANSFIELD JH, MCGLINN E Evolution, expression, and developmental function of Hox-embedded miRNAs. Curr Top Dev Biol 2012; 99: 31-57. http://dx.doi.org/10.1016/B978-012-387038-4.00002-1

[20] WAN G, MATHUR R, HU X, ZHANG X, LU X miRNA response to DNA damage. Trends Biochem Sci 2011; 36: 478-484. http://dx.doi.org/10.1016/j.tibs.2011.06.002

[21] UENO K, HIRATA H, HINODA Y, DAHIYA R Frizzled homolog proteins, microRNAs and Wnt signaling in cancer. Int J Cancer 2013; 132: 1731-1740. http://dx.doi.org/10.1002/ ijc. 27746

[22] WANG Q, WANG S, WANG H, LI P, MA Z MicroRNAs: novel biomarkers for lung cancer diagnosis, prediction and treatment. Exp Biol Med (Maywood) 2012; 237: 227-235. http://dx.doi.org/10.1258/ebm.2011.011192

[23] PARANJAPE T, CHOI TJ, WEIDHAAS JB MicroRNA as Potential Diagnostics and Therapeutics. In: Slack FJ, editor. MicroRNAs in Development and Cancer. London: Imperial College Press, 2011: 213-236.

[24] GRIFFITHS-JONES S The microRNA Registry. Nucleic Acids Res 2004; 32(Database issue): D109-111.
[25] DONADELLI M, DANDO I, FIORINI C, PALMIERI M Regulation of miR-23b expression and its dual role on ROS production and tumor development. Cancer Lett 2014; 349: 107-113. http://dx.doi.org/10.1016/j.canlet.2014.04.012

[26] MAJID S, DAR AA, SAINI S, ARORA S, SHAHRYARI V et al. miR-23b represses proto-oncogene Src kinase and functions as methylation-silenced tumor suppressor with diagnostic and prognostic significance in prostate cancer. Cancer Res 2012; 72: 6435-6446. http://dx.doi.org/10.1158/0008-5472. CAN-12-2181

[27] CASTILLA MÁ, MORENO-BUENO G, ROMERO-PEREZ L, VAN DE VIJVER K, BISCUOLA M et al. Micro-RNA signature of the epithelial-mesenchymal transition in endometrial carcinosarcoma. J Pathol 2011; 223: 72-80. http://dx.doi. org/10.1002/path.2802

[28] MAJID S, DAR AA, SAINI S, DENG G, CHANG I et al. MicroRNA-23b functions as a tumor suppressor by regulating Zeb1 in bladder cancer. PLoS One 2013; 8: e67686. http:// dx.doi.org/10.1371/journal.pone.0067686

[29] JIN L, WESSELY O, MARCUSSON EG, IVAN C, CALIN GA et al. Prooncogenic factors miR-23b and miR-27b are regulated by Her2/Neu, EGF, and TNF- $\alpha$ in breast cancer. Cancer Res 2013; 73: 2884-2896. http://dx.doi.org/10.1158/00085472.CAN-12-2162

[30] CHEN L, HAN L, ZHANG K, SHI Z, ZHANG J et al. VHL regulates the effects of miR-23b on glioma survival and invasion via suppression of HIF-1 $\alpha$ /VEGF and $\beta$-catenin/Tcf-4 signaling. Neuro Oncol 2012; 14: 1026-1036. http://dx.doi. org/10.1093/neuonc/nos122

[31] ZAMAN MS, THAMMINANA S, SHAHRYARI V, CHIYOMARU T, DENG G et al. Inhibition of PTEN gene expression by oncogenic miR-23b-3p in renal cancer. PLoS One 2012; 7 : e50203. http://dx.doi.org/10.1371/journal.pone.0050203

[32] DETTMER MS, PERREN A, MOCH H, KOMMINOTH P, NIKIFOROV YE et al. MicroRNA profile of poorly differentiated thyroid carcinomas: new diagnostic and prognostic insights. J Mol Endocrinol 2014; 52: 181-189. http://dx.doi. org/10.1530/JME-13-0266

[33] KENNEDY BG, MANGINI NJ P-glycoprotein expression in human retinal pigment epithelium. Mol Vis 2002; 8: 422-430.

[34] CARDANO M, DIAFERIA GR, FALAVIGNA M, SPINELLI CC, SESSA F et al. Cell and tissue microarray technologies for protein and nucleic acid expression profiling. J Histochem Cytochem 2013; 61: 116-124. http://dx.doi. org/10.1369/0022155412470455

[35] PARK YT, JEONG JY, LEE MJ, KIM KI, KIM TH et al. MicroRNAs overexpressed in ovarian ALDH1-positive cells are associated with chemoresistance. J Ovarian Res 2013; 6: 18. http://dx.doi.org/10.1186/1757-2215-6-18

[36] DINGEMANS AM, VAN ARK-OTTE J, VAN DER VALK P, APOLINARIO RM, SCHEPER RJ et al. Expression of the human major vault protein LRP in human lung cancer samples and normal lung tissues. Ann Oncol 1996; 7: 625-630. http:// dx.doi.org/10.1093/oxfordjournals.annonc.a010681

[37] ARTS HJ, KATSAROS D, DE VRIES EG, MASSOBRIO M, GENTA F et al. Drug resistance-associated markers P-glycoprotein, multidrug resistance-associated protein 1 , multidrug 
resistance-associated protein 2 , and lung resistance protein as prognostic factors in ovarian carcinoma. Clin Cancer Res 1999; 5: 2798-2805.

[38] POHL G, FILIPITS M, SUCHOMEL RW, STRANZL T, DEPISCH D et al. Expression of the lung resistance protein (LRP) in primary breast cancer. Anticancer Res 1999; 19: 5051-5055.

[39] MIYATAKE K, GEMBA K, UEOKA H, NISHII K, KIURA $\mathrm{K}$ et al. Prognostic significance of mutant p53 protein, Pglycoprotein and glutathione S-transferase-pi in patients with unresectable non-small cell lung cancer. Anticancer Res 2003; 23: 2829-2836.

[40] CHEN ZJ, LE HB, ZHANG YK, QIAN LY, SEKHAR KR et al. Lung resistance protein and multidrug resistance protein in non-small cell lung cancer and their clinical significance. J Int Med Res 2011; 39: 1693-1700. http://dx.doi. org/10.1177/147323001103900511

[41] BERGER W, SETINEK U, HOLLAUS P, ZIDEK T, STEINER E et al. Multidrug resistance markers P-glycoprotein, multidrug resistance protein 1 , and lung resistance protein in non-small cell lung cancer: prognostic implications. J Cancer Res Clin Oncol 2005; 131: 355-363. http://dx.doi.org/10.1007/s00432$\underline{004-0653-9}$

[42] IZQUIERDO MA, VAN DER ZEE AG, VERMORKEN JB, VAN DER VALK P, BELIËN JA et al. Drug resistance-associated marker Lrp for prediction of response to chemotherapy and prognoses in advanced ovarian carcinoma. J Natl Cancer Inst 1995; 87: 1230-1237. http://dx.doi.org/10.1093/ jnci/87.16.1230

[43] FILIPITS M, DRACH J, POHL G, SCHUSTER J, STRANZL $T$ et al. Expression of the lung resistance protein predicts poor outcome in patients with multiple myeloma. Clin Cancer Res 1999; 5: 2426-2430.

[44] FILIPITS M, STRANZL T, POHL G, HEINZL H, JAGER $\mathrm{U}$ et al. Drug resistance factors in acute myeloid leukemia: a comparative analysis. Leukemia 2000; 14: 68-76. http:// dx.doi.org/10.1038/sj.leu.2401634 